The species accounts begin with two lizards (the Gila Monster and the Mexican Beaded Lizard, genus Heloderma), the sole members of their family and the only venomous reptiles other than snakes in the world. Two families of snakes follow (Elapidae, including here the coral snakes and the sea snakes) and Viperidae (here represented by pitvipers) in 190 species accounts. Omitted are the few poisonous rear-fanged Colubridae. Volume 1 contains all species except the rattlesnakes, while Volume 2 covers the latter.

The species accounts lead with scientific name and original describer and date, reference to figure (drawing), map (with dots of collections and shading for the suggested range), and plates (colour photographs), synonymy, local names, English name, and etymology. For some species a quotation from an historical observation is added. Sections follow on distribution, habitat, description, similar species, and remarks (including described subspecies and relationships with other species).

As comprehensive as these accounts are, there are other topics covered. In volume 1, there is an Introduction, Regional Accounts and separate Keys to Canada and United States, Mexico and Central America, The Caribbean Islands, and South America. Volume 2 includes chapters on Venomous Snake Mimicry, The Evolution of New World Venomous Snakes, Venom Poisoning by North American Reptiles, and Snakebites in Central and South America: Epidemiology, Clinical Features Management. The volume has an 11-page Glossary, and a 116-page Literature Cited. A 28-page index is repeated to conclude each volume.

Canada has only three Crotalus: The Timber Rattlesnake $C$. horridus (Ontario, now extirpated), Prairie

\section{Whales and Dolphins of the World}

By M. Simmonds. 2004. The MIT Press, Five Cambridge Centre, Cambridge Masachusetts 02142. 160 pages, U.S. \$29.95 Cloth.

Coffee table books of cetaceans seem to be popular with authors, photographers and the buying public. Here is another fine example. I note my local library has three shelves of mammal books. Almost 20\% are on whales and the other books cover the rest of the world's 5000 or so species of mammal, a testament to the popularity of cetaceans.

While this book does not cover all the world's species it does have photographs of over 50 per cent. As you would expect the photographs are remarkably good. All the common species (common that is in books) like Blue, Sperm Humpback, Minke are there. But so too are some of the less well known and photographed, such as the Boto and Pink River Dolphin. These latter animals are not so difficult to see but are stunningly hard to capture on film.

The first half of the book is devoted to basic information on whales, similar to that found in most volumes of this type. The second half has information on the threats faced by these animals and the conservation
Rattlesnake C. viridis (Saskatchewan and Alberta), Pacific Rattlesnake C. oreganus (British Columbia) and one Sistrurus, the Massasauga S. catenatus (Ontario). Despite the through coverage elsewhere, the peripheral nature of their distributions here may account for the scant coverage of Canadian references the southernbased authors have included. Some relatively recent contributions by Pat Weatherhead formerly at Carleton University, Tony Russell at University of Calgary, and Pat Gregory at the University of Victoria and their many students are included. However, some citations for Canadian distributions are merely popularized accounts by non-Canadians such Curran's 1935 rattlesnake article in the American Museum's Natural History or Kozloff's 1976 book an animals of the Pacific northwest. Many are dated, the citation to the pioneering Canadian checklist by Logier and Toner is to the first (1955) edition rather than 1961 revision. Two references to Barbara Froom are to 1964 and 1967 articles or pamphlets whereas her 1972 book is omitted. The detailed distributional documentation in the Ontario Herpetofaunal Summary and the status reports of Committee on the Status of Endangered Species of Wildlife in Canada (COSEWIC), or the symposiums on the Massasauga and conservation promotional newsletter Rattlesnake Tales sponsored by the Metro Toronto Zoo are ignored, perhaps because they are not readily accessible in the mainstream literature.

FRANCIS R. COOK

Researcher Emeritus, Canadian Museum of Nature, Ottawa, Ontario K1P 6P4 Canada

measures in place or necessary. I also has a very odd error. The author writes of the Basques from northern France. Any Basque will tell they always lived in the Pyrenees Mountains of northern Spain and southern France.

The author list 83 species of whales and dolphins; one short of the most current list. The missing species is North Pacific Right Whale (Eubalaena japonica), recently separated by Rosenbaum et al, based on DNA. [This counting does not include Delphinus tropicalis as this is likely a variant of $D$. capensis and not a separate $84^{\text {th }}$ species]

Why should I buy this book? I can think of three reasons. Any good whale book is worth having, especially when it such fine photos. The latter half of the book contains new and up-to-date information of importance. The royalties from sales are going to the Whale and Dolphin Conservation Society, where the author is Director of Science at the aforementioned society.

ROY JOHN

2193 Emard Crescent, Beacon Hill North, Ottawa, Ontario K1J 6K5 Canada 